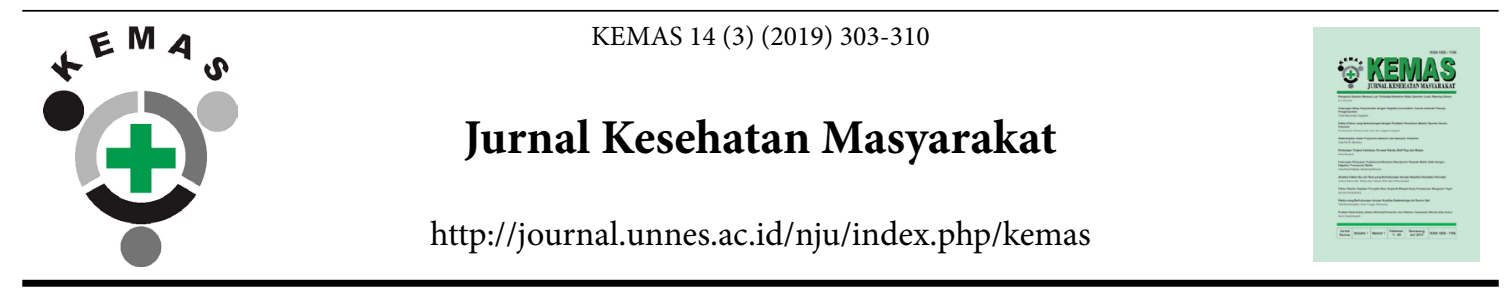

\title{
Mapping and Analysis of Hepatitis A Disease Distribution Based on Risk Factors in Bondowoso District
}

\author{
Faiqatul Hikmah ${ }^{1}$, Novita Nuraini ${ }^{1}$, Estu Pratika Sari ${ }^{1}$ \\ ${ }^{1}$ Prodi Rekam Medik Jurusan Kesehatan, Politeknik Negeri Jember, Indonesia
}

\begin{tabular}{l} 
Article Info \\
\hline Article History: \\
Submitted September 2017 \\
Accepted August 2018 \\
Published March 2019 \\
\hline Keywords: \\
Mapping, HAV, \\
ArcView GIS 3.3 \\
\hline DOI \\
https://doi.org/10.15294/ \\
kemas.v14i3.11246
\end{tabular}

\begin{abstract}
Hepatitis A is caused by the Hepatitis A virus (HAV). Bondowoso experienced an Extraordinary Occurrence HAV with 60 patients who were mostly teenagers. This study aimed to map and analyze the distribution of HAV based on risk factors in Bondowoso in 2016. This was descriptive research and application which was used to create digital map ArcView GIS 3.3. The result of this research was a map of HAV distribution and risk factor in Bondowoso. Mapping results showed that the risk factors cause HAV outbreak in Bondowoso were unhealthy living behaviors, Open Defecation, and rainfall intensity. The population density was not a risk factor due to outbreaks or extraordinary occurrences of hepatitis A occurred in areas of low population density. Suggestion for the Health Department to cooperate with an educational institution to increasing of clean and healthy behaviors Additionally, Hepatitis A immunization, and provide clean water.
\end{abstract}

\section{Introduction}

Hepatitis $\mathrm{A}$ is a disease caused by the Hepatitis A virus (HAV). Hepatitis A infection often occurs in the form of outbreaks with a common source pattern, generally, the source of transmission comes from drinking water and contaminated food, uncooked food, and poor sanitation. In addition, although it is not the main method of transmission, transmission through transfusion or the use of used needle syringes during the incubation period has also been reported (Kemenkes RI, 2012).

WHO estimates that in the world there are around 1.4 million people with Hepatitis A. Each year the incidence of Hepatitis A in Europe in 2008 is 3.9 per 100,000 population. The incidence of Hepatitis A in America in 2009 was 1 per 100,000 people, with an estimated
21,000 people. Hepatitis A cases in Indonesia often appear in Indonesian Outbreaks. In 2010 there were 6 outbreaks with 279 sufferers, while in 2011 there were 9 outbreaks, 550 patients. In June 2012, there were 4 outbreaks with 204 patients. In 2004 there were 47 hepatitis A cases in Bondowoso, East Java. In 2006 there 65 cases in Pakem, Bondowoso, East Java (Kemenkes RI, 2012). In 2013 cases of hepatitis A reached 20 cases. In 2014, there were no cases of hepatitis A in Bondowoso district. In 2015 there were 71 cases of hepatitis A (Dinkes Bondowoso, 2015). Based on a preliminary study conducted by researchers, in January 2016 Bondowoso district experienced hepatitis A Extraordinary Events with the number of patients reaching 60 people, the majority of whom were teenagers with 10 15 years age groups (Dinkes Bondowoso, 2016). 
Hepatitis A and Hepatitis E have an orofecal transmission mechanism (transmitted through food and/or drinks that have been contaminated with feces) containing Hepatitis $\mathrm{A}$ and $\mathrm{E}$ viruses. This is very related to bad environmental conditions, such as lack of clean water supply, sanitary sewage and garbage disposal, personal hygiene and poor sanitation (Kemenkes RI, 2012). According to research in Korea, poor environmental sanitation and high population density will increase the risk of hepatitis A (Seo et al., 2012).

The advancement of information technology is very important and very much needed by the community, one of which is the need for geographic information, wherein managing this diverse data requires an information system that is capable of integrated in processing spatial and non-spatial data effectively and efficiently, one of which is the Geographic Information System or often called GIS (Nugroho, Guruh Sabdo, 2013). The importance of conducting a distribution map of an illness is to study the factors that influence in terms of agent, host, environment, and geography that are very useful to help implement the plan appropriately (Indriasih, 2008). In each region has a different environment in the form of the social environment, natural environment, and built environment, the potential of the community based on the environment will also be different (Oktia, 2012).

Presentation of information in the form of mapping can meet the requirements for quality information, namely the relevance that the information produced is directly related to the program in the Health Office, accurate and complete data and information needs from the Public Health Center (Puskesmas) level are needed in its development (Setyowati and Astuti, 2015). In addition, the presentation of health data using a GIS (Geographic Information System) strongly supports activities in monitoring and can be used to develop health policies and health planning for nutritional status, especially in relation to the allocation of resources at the district level (Setyowati and Astuti, 2015).

Method

Analyzes the distribution of hepatitis A based on risk factors in Bondowoso district was using ArcView GIS 3.3, which was supported by data on the distribution of hepatitis A and risk factor data. The risk factors studied include clean and healthy living behavior, sanitation, population density and rainfall in Bondowoso Regency. Each risk factor data were classified into three classes, namely low, medium and high. The research was conducted in Bondowoso District starting in July 2016 until July 2017. The data collection techniques carried out for primary data were interviews about preventive measures carried out by the Bondowoso district health office related to the high incidence of hepatitis A, while secondary data was documented by data obtained from Bondowoso District Health Office and Central Statistics Agency. The results of data collection will be processed and analyzed by comparing the facts with the existing theories. The results were presented in the form of digital maps (softcopy) along with tabular data and analysis.

\section{Result and Discussion}

In Bondowoso District, the Sub-districts that have the highest cases of the spread of hepatitis A were Wringin Sub-district with 47 people and Pakem Sub-district 13 people. There were more men sufferers than women. Hepatitis A sufferers in Wringin with 32 men and 15 women. In Pakem Sub-district there are 8 men sufferers and 5 women sufferers. The distribution of Hepatitis A in Bondowoso Regency in 2016 mostly occurs in men rather than women. This was in line with previous studies, namely the distribution of Hepatitis A cases in Jember in 2013 was mostly found in men than women (Ramani, 2017). Evidence that men are more susceptible to Hepatitis A was because men have a lower awareness of their health and more often consume food outside the home (Umar, 2005).

Hepatitis A outbreaks in 2016 mostly occur in elementary and middle school students with an age range of 10-15 years who are categorized as children. All age groups were prone to infection with Hepatitis A virus with the highest group in children and young adults. In the study in Jember, the spread of Hepatitis A was spread unevenly in each age range, when viewed from the age group with the highest number of Hepatitis A patients age 21-30 years with the number of patients 51 people $(27.87 \%)$ 
and the age group that has the least number of Hepatitis A patients is the age group 71-80 years with the number of patients 2 people $(1.09 \%)$ (Ramani, 2017).

Based on the results of interviews with P2PL officers, the number of sufferers among school children was caused by the habit of snacking carelessly and not accustomed to washing hands with soap. Hepatitis A disease was included in the indirect transmission. Food snacks play an important role in providing energy and other nutrients for school-age children. Consumption of snacks should be considered because of the high activity of children (Khairuna et al., 2012). Generally, Hepatitis A is spread fecal-oral from human to human using objects or cutlery that have been contaminated with HAV (Hepatitis A Virus) or have food and beverages that have been contaminated by infected feces. Therefore, Hepatitis A virus easily spreads in areas with poor sanitation and unattended personal hygiene (Ramani, 2017). There are no detailed data on risk factors for hepatitis $\mathrm{A}$, but it is estimated that the most common is due to food contaminated with HAV (Dwika, 2013).

The hepatitis A distribution map is divided into three categories, namely low, medium, and high. Sub-districts with low hepatitis cases with numbers 0-4 include
Sempol, Sumberwringin, Tlogosari, Botolinggo, Sukosari, Pujer, Jambesari, Tamanan, Maesan, Grujugan, Curahdami, Binakal, Wonosari, Tenggarang, Bondowoso, Tapen, Tegal Ampel, Taman Krocok, Cermee, Prajekan, and Klabang. Districts with moderate hepatitis cases with numbers 5-13 namely Pakem. Districts with high hepatitis cases with numbers 14-47 namely Wringin.

Unhealthy behavior in Bondowoso Regency is divided into three categories, namely low with yellow symbols, medium with orange symbols, and high with red symbols. Districts with low categories with numbers 0-526 include Curahdami, Bondowoso, Sukosari, and Taman Krocok. Sub-districts with moderate categories with numbers 527-1574 include Tamanan, Sumberwringin, Botolinggo, Grujugan, Binakal, Tegal Ampel, Klabang, Prajekan, and Wonosari. Districts with a high category with numbers 1575-3188 include Sempol, Tlogosari, Pujer, Jambesari, Maesan, Tenggarang, Tapen, Cermee, Pakem, and Wringin.

Based on the results of the mapping, there are two Sub-districts with moderate and high numbers of hepatitis A cases, namely Pakem and Wringin Sub-districts. Wringin Subdistrict was ranked first in the case of hepatitis A in Bondowoso District in 2016 with 47 cases. Whereas unhealthy living behavior in Wringin

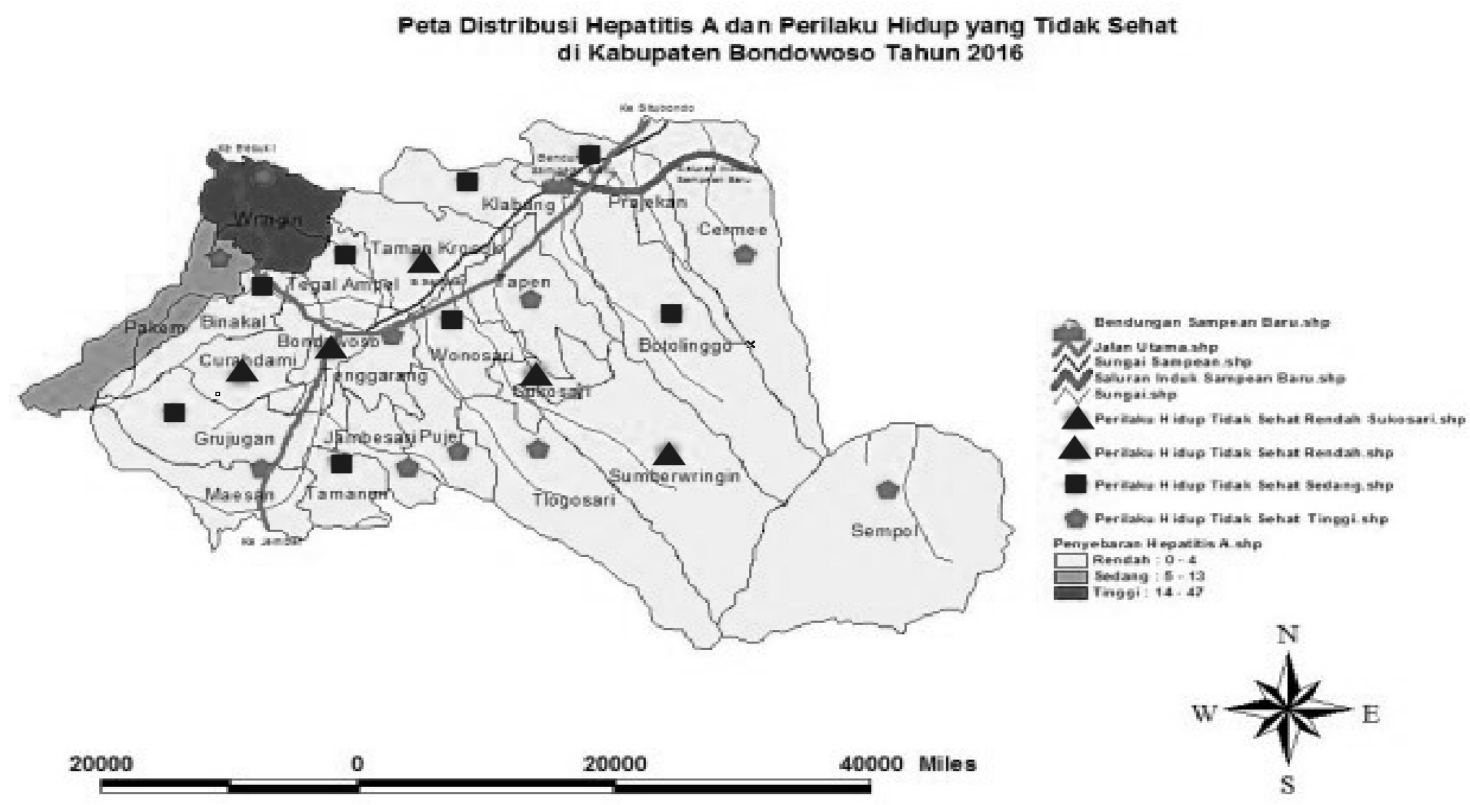

Figure 1. Map of Distribution of Hepatitis A and Unhealthy Behavior in Bondowoso District in 2016 
Sub-district is included in the high category which is a number of 2084. Pakem District is a Sub-district bordering Wringin. Pakem Subdistrict is included in the moderate category of Hepatitis A cases in Bondowoso Regency in 2016 with 13 cases. Whereas unhealthy living behavior in Pakem Sub-district is included in the high category, which is a number of 2011. This shows that hepatitis A in the Sub-district is caused by unhealthy behavior. This is in accordance with other studies in 2013, based on the results of mapping Hepatitis A cases and Hepatitis A risk mapping in Jember Regency, Hepatitis A cases illustrate that Sumbersari Subdistrict and Patrang Sub-district are included in the high category of Hepatitis A cases, this is due to risk factors not clean and healthy life behavior, defecation behavior not in healthy latrines, no family latrines, no access to clean water, unprotected sources of drinking water, unhealthy waste management, and unhealthy trash cans (Ramani, 2017).

Indicators of clean and healthy behavior, one of which is the behavior of washing hands with clean water and soap. Washing hands before eating and after bowel movements is one of the efforts made by humans to prevent food contamination by infectious agents such as viruses. Hepatitis A virus spreads through food or water contaminated with feces of infected people. This disease is very closely related to the lack of clean water, inadequate sanitation, and unhealthy behavior. The practice of poor hand washing is also a risk factor for hepatitis A disease because it results in a risk of HAV to enter the body when eating becomes large (Dwika, 2013).

Based on the description, it can be concluded that unhealthy behavior leads to high cases of hepatitis A in Bondowoso Regency in 2016. Efforts have been made by the Bondowoso District Health Office in the form of counseling about the importance of a clean and healthy lifestyle, washing hands with soap, defecating on the place and processing healthy food before consumption. Doing health promotion must be right on target, considering that this case is a lot at school age, so in school institutions in Indonesia can be done through formal health education as applied in the curriculum. Health promotion through informal channels, such as information health education, PHBS monitors, and distribution of health education books for teachers and parents (Oktia et al., 2017). In other studies to be able to improve knowledge in school-age children can use media comic media during health education (Khairuna $\mathrm{H} \&$ Siti Z, 2012).

\section{Peta Distribusi Hepatitis A dan Sanitasi (Open Defecation) di Kabupaten Bondowoso Tahun 2016}

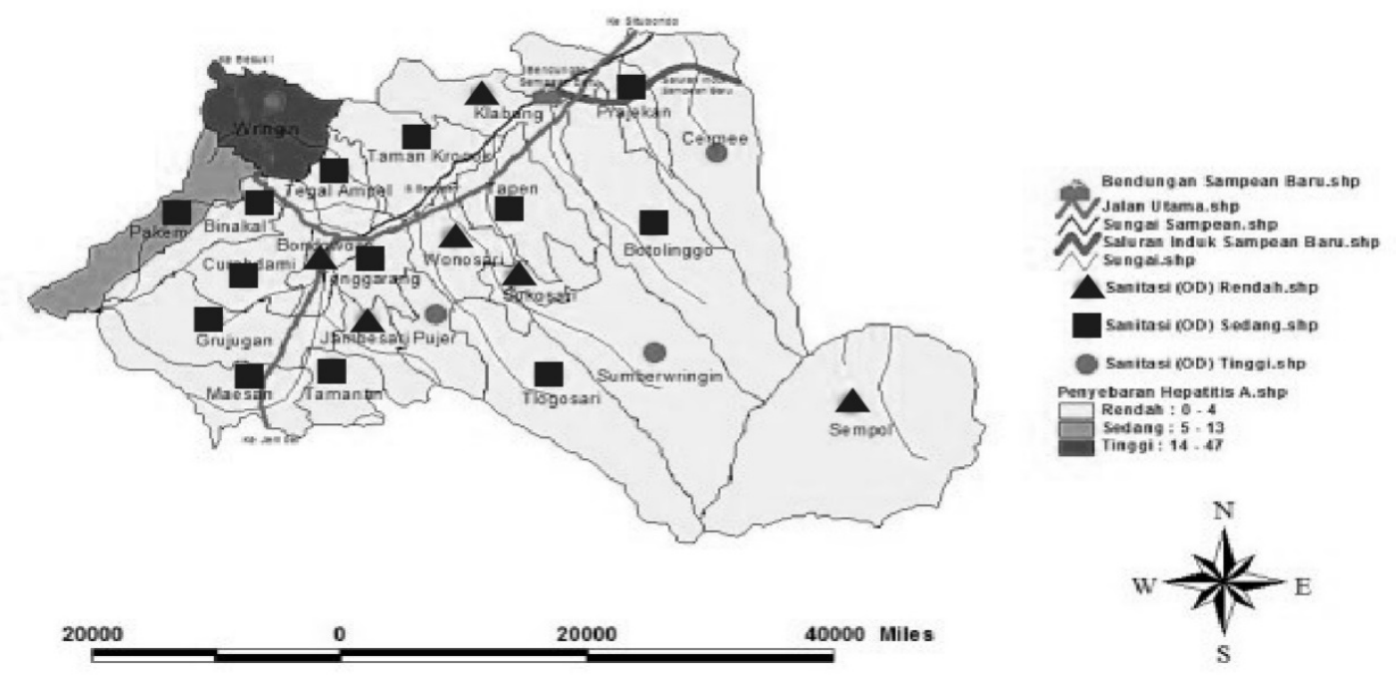

Figure 2. Map of Hepatitis A and Sanitation Distribution (Open Defecation) in Bondowoso District in 2016 
The hepatitis A distribution map is divided into three categories, namely low, medium, and high. Sub-districts with low hepatitis cases with numbers $0-4$ include Sempol, Sumberwringin, Tlogosari, Botolinggo, Sukosari, Pujer, Jambesari, Tamanan, Maesan, Grujugan, Curahdami, Binakal, Wonosari, Tenggarang, Bondowoso, Tapen, Tegal Ampel, Taman Krocok, Cermee, Prajekan, and Klabang. Districts with moderate hepatitis cases with numbers 5-13 namely Pakem. Districts with high hepatitis cases with numbers 14-47 namely Wringin.

Based on the results of other studies showing there is a relationship between knowledge and the high number of Open Defecation (Qudsiyah et al, 2015). Sanitation (Open Defecation) is divided into three categories, namely low with a round shape symbol of pastel color, medium with a round shape symbol in orange, and high with a red round symbol. Low category Sanitation (Open Defecation) districts include Sempol, Klabang, Sukosari, Wonosari, Bondwoso, and Jambesari. Medium category of Sanitation (Open Defecation) Sub-districts includes Tlogosari, Botolinggo, Tapen, Prajekan, Taman Krocok, Tegal Ampel, Binakal, Pakem, Curahdami, Tenggarang, Grujugan, Maesam, Tamanan. The high category Open Defecation Sub-districts include Wringin, Sumberwringin, Pujer, and Cermee. Based on the results of the mapping, there are four high category Open Defecation Sub-districts covering Wringin, Sumberwringin, Pujer, and Cermee. While the number of Hepatitis A cases in Wringin Sub-district was 47 cases, Sumberwringin 1 case, Pujer 0 cases, and Cermee 2 cases. Sumberwringin, Pujer, and Cermee Subdistricts are located far away from Wringin as the highest Sub-district with hepatitis A, making it less likely that these three Subdistricts will be infected with the hepatitis A virus through contaminated river water due to Open Defecation behavior.

The high level of sanitation (Open Defecation) in Wringin Sub-district with the amount of 7,645 is a factor of the high case of hepatitis A. Hepatitis A has a mechanism of oral-fecal transmission (transmitted through food and/or drinks contaminated with feces) containing the Hepatitis A. this is very related to bad environmental conditions, such as lack of clean water supply, sanitary sewage and garbage disposal, personal hygiene and poor sanitation (Kemenkes RI, 2012). The habit of defecating anywhere / not in a healthy toilet or Open Defecation (OD) is also a factor that supports high hepatitis A cases. Similar to the results of other studies, that poor utilization of latrines was statistically significant as a risk factor for hepatitis A outbreaks in primary school children in Kintamani (I Gede \& I Gusti, 2014). Based on other studies stated that there is a relationship between feces disposal facilities and the incidence of diarrhea, where respondents who do not have latrines will have the potential to cause diarrheal disease, because toilet facilities that are not easily flushed and feces that are not covered and treated closed will be accessible to cause vectors Diarrheal diseases which will indirectly contaminate food or drinks. In addition, the distance between the manure pit and the source of clean water or a well less than 10 meters, will cause germs that cause diarrhea originating from feces contaminating clean water sources that people use for their daily needs (Lailatul M, 2013).

Pakem is a Sub-district bordering Wringin. Pakem is in the moderate category of cases of hepatitis A with a total of 13 cases. Sanitation (Open Defecation) in Pakem Subdistrict is in the moderate category of 5718 . The location of Pakem which borders Wringin is the cause of many cases of hepatitis A in the Sub-district. Transmission of hepatitis A can occur through intermediaries of various media including feces containing hepatitis A. The process of transmitting hepatitis A infectioncausing agents through " $4 \mathrm{~F}$ ", namely Fluids, Fields, Flies and Fingers, this cycle starts from contamination of human feces through water and soil pollution, spread of insects and dirty hands that are transferred to food so that they are consumed by humans or fecal-oral transmission. This is in accordance with other studies, showing that respondents with a toilet condition were at risk with the chance of acute clinical hepatitis at 10.06 times compared to respondents who were not at risk of the toilet (Umar F, 2005).

According to research in Korea, poor 
environmental sanitation and high population density will increase the risk of hepatitis $A$ people who live in areas with poor sanitation have a higher risk. Poor sanitation systems make the transmission of diseases easier, so more cases emerge (Seo et al., 2012).

Based on the description it can be concluded that poor sanitation (Open Defecation) causes a high number of hepatitis A cases in Bondowoso Regency in 2016. Efforts made by the Bondowoso District Health Office to reduce the high number of Open Defecation are still in the form of policies governing the provision of family / public latrines.

Febrian Ade (2015) stated that population density supported by residential density is a fertile nursery for viruses and germs. Dense occupancy can facilitate transmission through the air. High population density allows the spread of germs to be faster. In general, the densely populated environment of awareness to maintain environmental cleanliness (both sanitation and hygiene) is greatly reduced, this situation may occur because of busy fulfilling daily necessities so that concern for the environment decreases, consequently the spread of disease outbreaks becomes faster and efforts to overcome them become more difficult.
Wringin and Pakem Sub-districts are the two highest areas of hepatitis A cases with relatively low population density. The population density for Wringin Sub-district is 905 people $/ \mathrm{km}^{2}$ and Pakem is 297 people/ $\mathrm{km}^{2}$. Whereas for Sub-districts with the highest population density there are only 2 sufferers of hepatitis A. This shows that population density is not always a factor in the occurrence of hepatitis A. It is different from the theory proposed by Gordon Le Richt, namely the highest incidence of Hepatitis A transmission in the region with high population density. Higher disease transmission occurs in poor sanitation hygiene and a densely populated environment (Satyabakti, 2013).

Population density basically impacts negative behavior on the personal hygiene of the community, which will tend to not pay too much attention to health status. In areas with such characteristics, infection with hepatitis A infectious diseases will easily spread and potentially become an outbreak (Kemenkes RI, 2012). However, this factor does not apply to Wringin and Pakem Sub-districts where population density is relatively low.

Based on the results of the mapping shows that the Pakem, Bondowoso, Wringin, and Cerme are Sub-districts with high rainfall

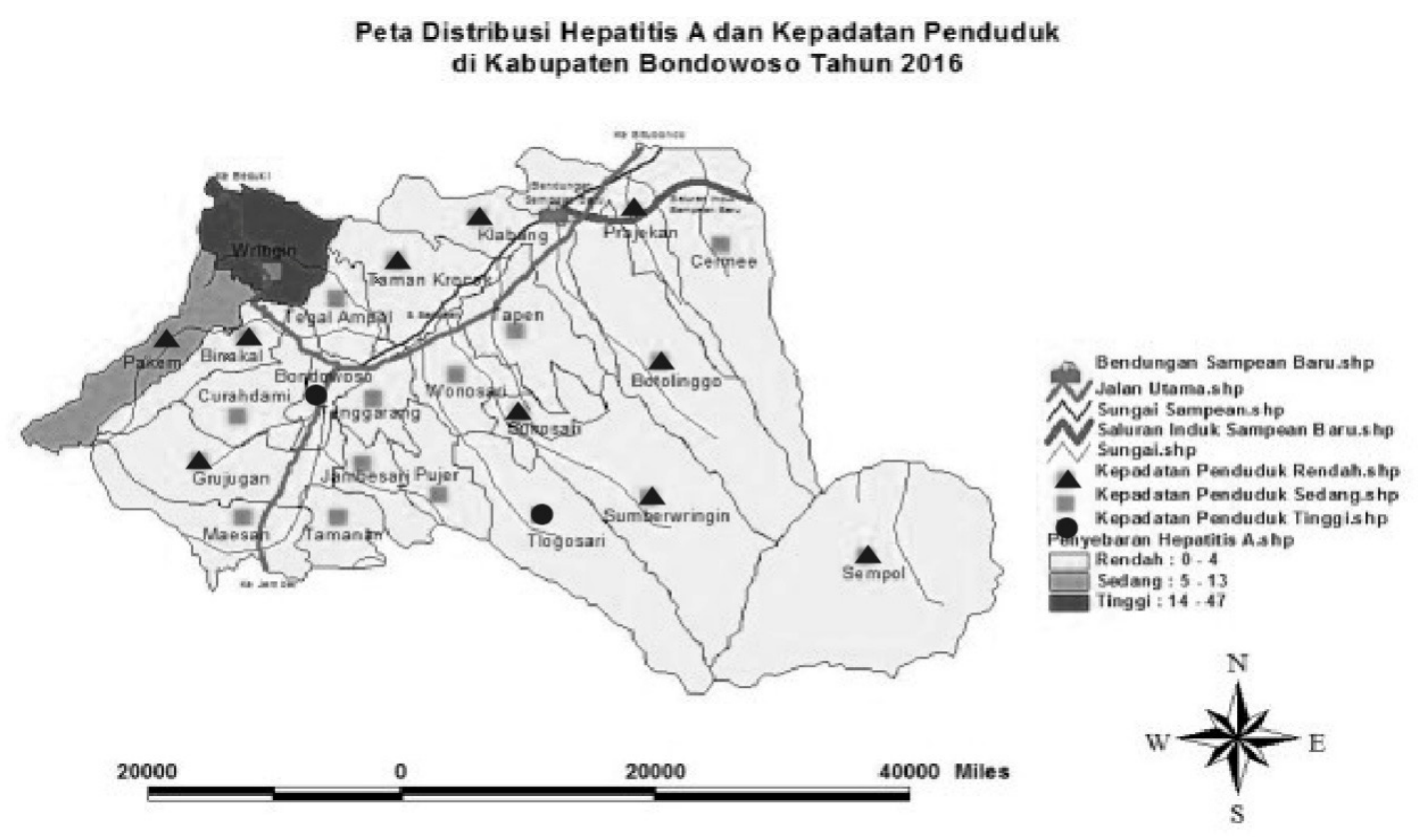

Figure 3. Map of Hepatitis A Distribution and Population Density in Bondowoso District in 2016 


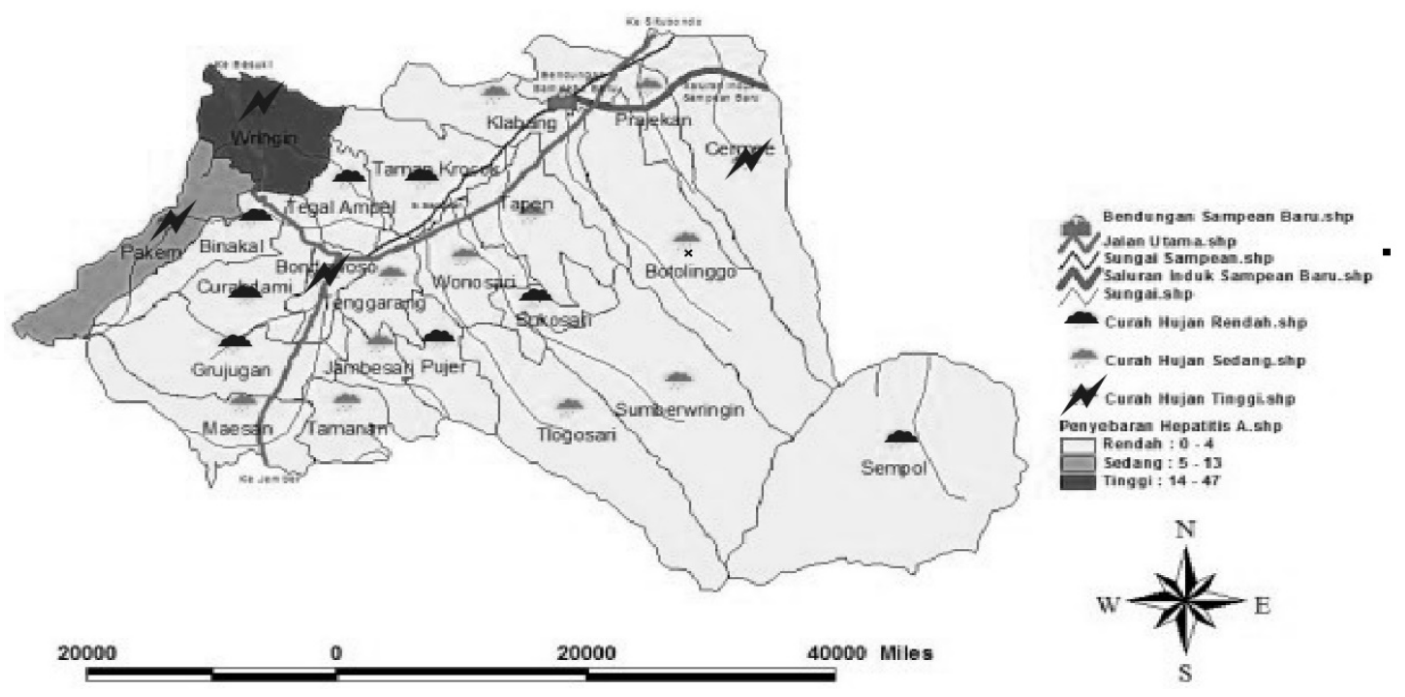

Figure 4. Map of Distribution of Hepatitis A and Rainfall in Bondowoso District in 2016

levels. The highest rainfall level in Pakem Subdistrict with $397 \mathrm{~mm}$ followed by Bondowoso Sub-district with $369 \mathrm{~mm}$ then Wringin Subdistrict with $315 \mathrm{~mm}$ and Cerme Sub-district with $284 \mathrm{~mm}$. Pakem including Sub-districts with moderate Hepatitis A cases with 13 cases and Wringin Sub-district is the first highest Sub-district of Hepatitis A with 47 cases in 2016. Sub-districts with the lowest rainfall in Bondowoso are Binakal Sub-districts with 85 $\mathrm{mm}$ and Hepatitis A cases are low with 3 cases.

Climate affects the pattern of infectious diseases in terms of viruses, bacteria or parasites and vectors. Climate and its variables, temperature, rainfall, and humidity are important parts of vector-based disease transmission. Infectious diseases, especially those that are sensitive to climate, will be greatly affected when climate change occurs. Climate change will make temperatures rise, rainfall increases and so does humidity (Sulistyawati, 2015). Weather affects the transportation and spread of microbial agents through rainfall. Water-borne diseases can be infected by many exposure routes, such as the vulnerability of individuals or populations, transmission of pathogens through water, sanitation, and clean behavior, all play a role (Sudarso, 2009).

Outbreaks of hepatitis A in Wringin and Pakem Sub-districts occur during high rainfall. This shows that the high incidence of Hepatitis
A in the Sub-district is indirectly caused by rainfall. In accordance with the study of the peak incidence of HAV infection on the coast of Rio de Janeiro in Brazil, it was found during the rainy season. These findings indicate that HAV infection spreads indirectly through rainfall because rainwater usually fills the river so they can overflow and people can be contaminated with the water. Hepatitis A virus is a virus that is very stable and can last 12 weeks to 10 months in water. This stability accounts for the frequent occurrence of waterborne (Fares, 2015).

Based on the description, it can be concluded that the incidence of hepatitis A in Bondowoso Regency is caused by high rainfall. Rainfall is not a direct cause but helps spread and transmit the HAV virus through contaminated river water. This is related to the habits of residents who still use the river as a place for defecation (open defecation) and other activities.

It has been carried out by the Bondowoso District Health Office to reduce the risk of Hepatitis A transmission through water by providing clean water for consumption by the community (PDAM), with the hope that people will not use river water for more activities.

The weakness of this study is that researchers cannot see cases of hepatitis $\mathrm{A}$ in a period. Basically, hepatitis A often occurs in the form of epidemics and at certain times. Data on 
hepatitis A cases in this study are in the form of data in one year and there are no known developments every month. Making maps in this study is desktop based and is not connected to the internet so data cannot be updated to determine the development of hepatitis A in Bondowoso District. In addition, data from the Bondowoso District Health Office only show that most hepatitis A sufferers are from the age group of 10-15 years who are mostly of school age. However, the researchers did not know about the facilities available for the needs of hand washing and toilets in schools in the highest region of hepatitis $\mathrm{A}$.

\section{Conclusion}

The highest distribution of hepatitis A occurs in Wringin and Pakem Sub-districts. The majority of sufferers in school-age children are due to careless snacking habits and are not used to washing hands with soap. The map of the distribution of hepatitis A in Bondowoso Regency shows that the incidence of hepatitis $\mathrm{A}$ in the highest region is Wringin and Pakem caused by unhealthy behavior, poor sanitation like open defecation, and rainfall. The cases of hepatitis A in the highest region, Wringin and Pakem, were not caused by population density because hepatitis A cases occurred in areas with low population density.

\section{References}

Dinkes Bondowoso., 2015. Laporan Persebaran Penyakit Menular 2015. Bondowso.

Dinkes Bondowoso., 2016. Laporan Hasil Investigasi KLB Hepatitis A di Wilker Puskesmas Wringin dan Pakem. Bondowoso.

Dwika, S. S. P. S., 2013. Hubungan Antara Higiene Perseorangan Dengan Kejadian Hepatitis A Pada Pelajar / Mahasiswa. Jurnal Berkala Epidemiologi, 2(3), pp. 331-341.

Fares, A., 2015. Seasonality of Hepatitis: A Review Update. Journal of Family Medicine and Primary Care, 4(1), pp. 96-100.

I Gede, K. A., \& I Gusti, N. S. P., 2014. Faktor Risiko Kejadian Luar Biasa Hepatitis A di Sekolah Dasar Negeri Selulung dan Blantih, Kintamani. Medicina, 45(2), pp. 79-83.

Indriasih, E., 2008. Sistem Informasi Geografis (SIG) dalam Bidang Kesehatan Masyarakat. Buletin Penelitian Sistem Kesehatan, 11(1), pp. 99-104.

Kemenkes RI., 2012. Pedoman Pengendalian Hepatitis Virus. Jakarta: Direktorat Jenderal PP \& PL.
Khairuna, H., \& Siti, Z. M., 2012. Penyuluhan Gizi Dengan Media Komik Untuk Meningkatkan Pengetahuan Tentang Keamanan Makanan Jajanan. Jurnal Kesehatan Masyarakat, 8(1), pp. 67-73.

Lailatul, M., 2013.Ketersediaan Sarana Sanitasi Dasar, Personal Hygiene Ibu Dan Kejadian Diare. Jurnal Kesehatan Masyarakat, 8(2), pp. 176-182.

Nugroho, G. S., 2013.Geographic Information System Penyebaran DBD Berbasis Web di Wilayah Kota Solo. Jurnal TIKomSiN, 1(2), pp. 59-65.

Oktia W. K. H., Macdonald, D., McCuaig, T. L., Rahayu, I., Budiono, 1., \& Lukman, F., 2017. Substitution Program In Indonesia And Australia As Health Health Promotion Model At Schools (An effort To Decrease Obesity). Jurnal Kesehatan Masyarakat, 12(2).

Oktia, W. K. H., 2012. Daerah Positive Deviance Sebagai Rekomendasi Model Perbaikan Gizi. Jurnal Kesehatan Masyarakat, 7(2), pp. 102109.

Qudsiyah, W. A., Pujiati, R. S., \& Ningrum, P. T., 2015. Faktor-Faktor yang Berhubungan dengan Tingginya Angka Open Defecation ( OD ) di Kabupaten Jember (Studi di Desa Sumber Kalong Kecamatan Kalisat). e-Jurnal Pustaka Kesehatan, 3(2).

Ramani, A., 2017. Pemetaan Risiko Hepatitis A dengan Sistem Informasi Geografis ( SIG ) di Kabupaten Jember Pemetaan Risiko Hepatitis A dengan Sistem Informasi Geografis. e-Jurnal Pustaka Kesehatan, 2, pp. 361-368.

Seo, J. Y., et al.2012. Pattern of Hepatitis A Incidence According to Area Characteristics Using National Health Insurance Data. Journal of Preventive Medicine and Public Health, 45(3), pp. 164-173.

Setyowati, M. \& Astuti, R., 2015. Pemetaan Status Gizi Balita Dalam Mendukung Keberhasilan Pencapaian Millenium Development Goals (MDGs). Jurnal Kesehatan Masyarakat, 10(2), pp. 110-121.

Sudarso., 2009. Pengaruh Variabiltas Iklim Terhadap Perkembangan Water-Borne Diseases. Jurnal Ilmiah Kedokteran Wijaya Kusuma.

Sulistyawati., 2015. Dampak Perubahan Iklim Pada Penyakit Menular: Sebuah Kajian Literatur. Jurnal Kesehatan Masyarakat, 8(1), pp. 342348.

Umar, F., 2005. Cuci Tangan Sebelum Makan Menurunkan Risiko Kejadian Hepatitis Akut Klinis. Buletin Penelitian Kesehatan, Vol 33(3). 